\title{
Tekstid 16. ja 17. sajandi ratas- ja Malta ristidel
}

Pille Arnek

\begin{abstract}
Teesid: Vanimad osaliselt tänini säilinud eestlaste nimesid kandvad hauatähised on valdavalt Põhja-Eesti kirikuaedades asuvad 16. sajandi lõpu ja 17. sajandi kivist ratasristid. Tegemist on hästi viimistletud meistritöödega, millelt võib leida tekstikatkeid eesti kirjakeele arenguloo vanemast perioodist. Kasutussageduselt on ratasristid pigem erandlikud tähisetüübid, mida ei saanud endale lubada kaugeltki iga talupoeg. Kellele need ristid kuulusid? Kust selline komme siiamaile jõudis? Mida neile tähistele kirjutati ning milline oli meistrite kirjaoskus? Millist lisainfot annavad tähistele kirjutatud tekstid eesti keele ajaloo uurimisele? Püüan neile küsimustele vastata, lähenedes uurimisainesele interdistsiplinaarselt. Ratasristide kasutamise põhjalikumaks mõistmiseks tuleb lisaks keelelistele aspektidele arvestada ka nende kunstiajaloolist, etnograafilist ja usundiloolist tausta.
\end{abstract}

Märksõnad: epitaafid, hauatähised, keeleajalugu, ratasristid, 17. sajand

Varaseimad säilinud hauatähised Eestis on Saaremaal ja Lääne-Eesti kirikuaedades asuvad trapetsiaalsed hauaplaadid. Neist vanimad pärinevad 13. sajandi lõpust ja 14. sajandi algusest (Üprus 1987: 68), osa uurijaid peavad neid veelgi varasemaks (Loit 2004). Trapetsiaalsed hauaplaadid paistavad silma erineva sümboolika poolest. Sümbolid trapetsiaalsetel hauaplaatidel sarnanevad mitmel juhul Ojamaal kasutatud sümbolitega (Loit 2004). Muuhulgas esineb päikeseristi (rõngas- ehk ratasristi), mis oli siinmail sümbolina tuntud juba varasel rauaajal, kuid mille kasutamine keskmisel rauaajal vähenes (Kõuts \& Valk 1998: 16) ja nooremal rauaajal kadus sootuks. Ratasristi sümbol tuli uuesti kasutusse seoses trapetsiaalsete hauaplaatide levikuga, see oli üks sagedamini kasutatud sümboleid neil plaatidel. Trapetsikujuliste hauakivide mittekristlik sümboolika viitab tihedatele seostele muinasajaga (Valk 1994: 28), osavalt on põimitud paganlikud sümbolid ristiusu sümbolite ja kommetega (Markus 2003: 109). Ratasristi kasutamine sümbolina keskajal mõneks ajaks jälle vähenes, kuid mitte kauaks. 16. sajandi alguses hakati linnahoonete pea- 
sissekäikude kaunistamiseks massiliselt kasutama etikukive, sagedamini just rõngasetikuvormi, mis on väga lähedane rõngasristile (Üprus 1987: 125-126). Võimalik, et etikukivid andsid teatud määral tõuke ratasristide aktiivseks kasutuselevõtuks hauatähisena, sest samast sajandist pärinevad ka esimesed kirikuaedades asuvad ratasristid, 17. sajandist pärineb neid juba hulgaliselt. Samas tuleb kahtlemata arvestada naaberalade mõju, kus ratasristid jõudsid haudadele mõnevõrra varem.

Helmi Üprus (1971: 17) kirjutab, et Tallinna Toomkiriku juurest on leitud üks ratasristi tükk, mis võib pärineda 15. ja 16. sajandi vahetusest. Vanim kindlalt dateeritud rõngasrist on Pavel Wedde 1521. aastast pärinev hauarist Narvas (Odres 1974: 297), mille oli raiunud tõenäoliselt üks Tallinna meistritest (Üprus 1987: 126). Vanimad teadaolevad eestlaste nimesid kandvad kalmutähised pärinevad Kultuurimälestiste Riikliku Registri (www.register.muinas.ee) andmetel 1593. ja 1598. aastast. Tegemist on valdavalt vabade talupoegade ja mõisatöötajate hauatähistega. Harvem kuuluvad kivist ratasristid mitteeestlastele.

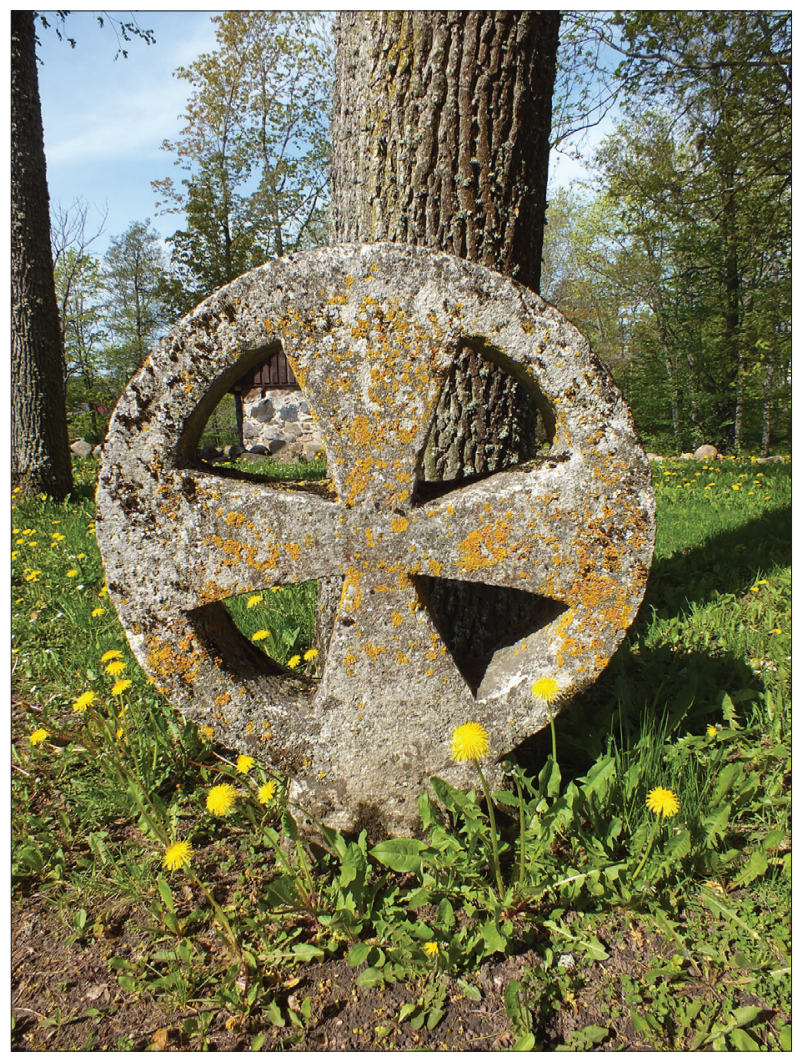

Foto 1. Tekstita ratasrist Palamuse kirikuaias. Pille Arneki foto 2014. 
Seega jõudsid esimesed eestlaste nimed kivist ratasristidele 16. sajandi lõpus. Kas ka varasematel puuristidel mingeid tekste peal oli, ei ole teada. Huvitav on aga asjaolu, et sisu poolest ei sarnane need tekstid sakslaste tähistega. Osa riste kannab kontrastselt primitiivset kirjapilti, millest võib järeldada, et kirja on kohapeal peale raiunud teine mees (Odres 1983). Kindlasti erinevad ratasristide tekstid täielikult kirikutes sees olevate hauaplaatide tekstidest, kus sakslased ise kasutasid ajastukohaselt tihti ladina keelt. Eestlaste tähised on lakoonilisemad, täpseid kuupäevi on kirjas harva. Sagedamini on mainitud päritolu ja elukutse. Ka on eestlaste tähised enamasti perekonnatähised. Sakslaste tähised on valdavalt pandud üksikisikule. Need sisaldavad täpseid kuupäevi. Esineb ka pöördumisi lugeja poole (nt Paluge tema hinge eest) ja piiblisalme, mida maarahva tähistelt ei leia.

\section{Varasemad uurijad ja allikad}

Ratasristid on kunstimälestisena kaitse all ja kajastatud Kultuurimälestiste Riiklikus Registris. Neid on müüritud kirikuseintesse - nii on toimitud näiteks kiriku laiendamisel ette jäänud ristidega. Kultuurimälestiste registris on kirjeldatud paraku ainult säilinud tähiseid. Ratasristide teemat on puudutatud erinevates artiklites ja kogumikes seoses hauatähiste ja matmiskommetega üldisemalt, aga ka kunstiajaloo seisukohalt. Mahuka töö on teinud etnoloog Lembit Odres, kes on koostanud ülevaate kõigist Eestis leiduvatest rõngasristidest ja neil olevatest tekstidest. Tema käsikirjalised materjalid on kättesaadavad Muinsuskaitsearhiivis, samuti Tallinna Ülikooli Akadeemilise Raamatukogu Baltika kogus pealkirja all "Eesti rõngasristid: uurimustöö kokkuvõte” (1983). Mitmesuguseid väiksema mahuga inventeerimismaterjale leiab erinevatest arhiividest. Vaimulik Ado Köögardal on Keila kirikuaia tähiseid üsna põhjalikult kirjeldanud raamatus Keila kihelkonnaloost (1924). Kunstiajaloolane Helmi Üprus (1987) puudutab ratasristide teemat seoses etikukivide kasutamisega hauatähistena. Nõnda on ratasristide teemat käsitlenud rohkemal või vähemal määral mitmel pool erinevad autorid ja uurijad (nt Mai Lumiste, Hendrik Olvi jt), kuid põhjalikumad kokkuvõtted ratasristide tekstidest senini puuduvad. Läti ratasristidest on Andris Caune (2008) kirjutanud raamatu Riņ̧,a krusti Latvija a, kus ta muuhulgas mainib, et kui rääkida naaberriikidest, leidub enim ratasriste just Eestis. Samas möönab ta, et kättesaadav kirjandus naaberriikide (sh Eesti) ratasristide kohta on ebapiisav või puudulik.

Ratasristi kujutis on olnud laialdaselt kasutusel ning seetõttu on raske kindlaks teha täpseid mõjutusi ja levikusuundi. Mälestuskivina või hauatähisena on ratasrist olnud kasutusel kõigis meie naabermaades, aga ka kaugemal 


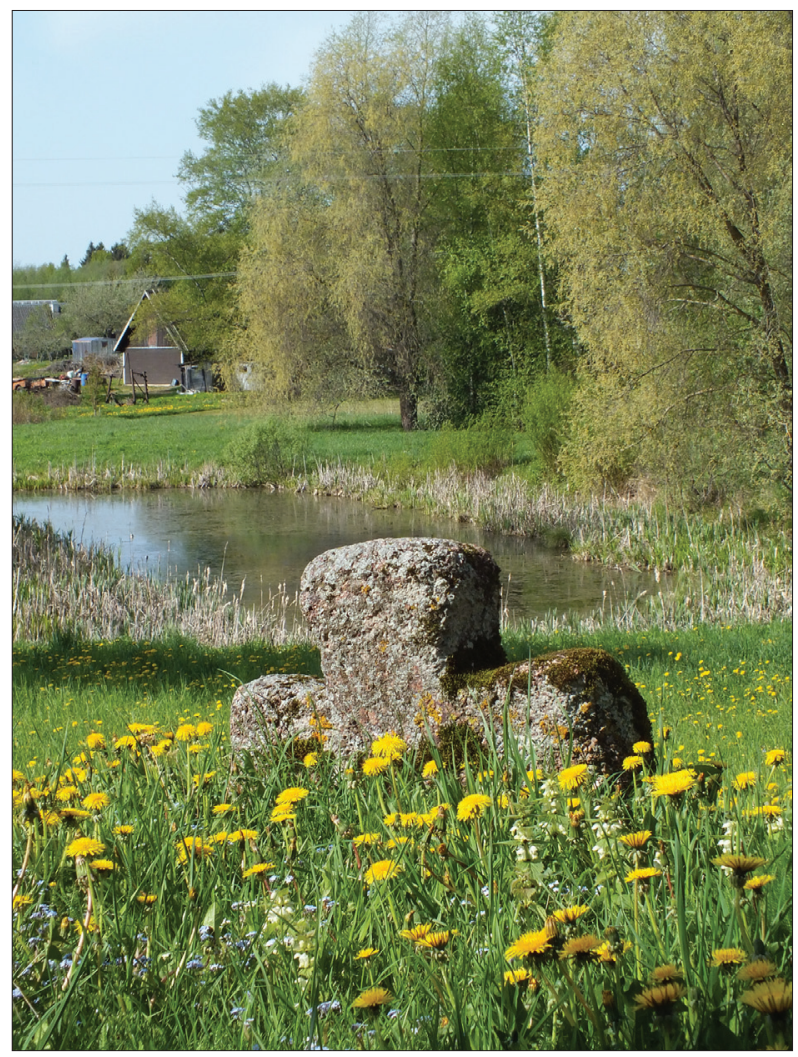

Foto 2. Kivirist Maarja-Magdaleena kirikuaias. Pille Arneki foto 2014.

Kesk- ja Põhja-Euroopas. Skåne rõngasristi kujutisega kivid Rootsis võivad pärineda 12.-13. sajandist (Caune 2008: 66). Rootsis leiab väljatahutud ratasristi hauatähisena näiteks Stockholmis Skanseni kalmistul, Soomes Helsingi Läänekalmistul (Odres 1983: 5-6). Lembit Odres (1983) kirjeldab mõningaid kivist ratasriste Moskvas, Irboskas ja Novgorodis. Novgorodi ümbruses on mitmete kirikute seintesse müüritud väiksemaid ratasriste. Novgorodi kremli muuseumide eksponaatide hulgast leiab kivist ratasriste, mis on dateeritud 14.-15. sajandisse. Lätist on Andris Caune (2008: 158) sõnul teada umbes 30 peamiselt 15.-16. sajandist pärinevat ratasristi, kuid säilinud on neist vaid 14. Leedus selline traditsioon puudub (Caune 2008; Odres 1983). Lisaks naaberaladele tuleb arvestada Saksamaa mõju, kus samuti leidub samatüübilisi ratasriste. Vanemate kivist ratasristide arv ja levik Eesti aladel võrreldes naabermaadega on aga kindlasti tähelepanuväärne. 
Odres (1983) kirjeldab oma materjalides 135 ratas- ja Malta risti, neist 12 on tema uurimuse koostamise hetkeks juba hävinud ning 35st on säilinud vaid fragmendid. Tänaseks on olukord veelgi muutunud. Tekstiga tähiseid 16.-17. sajandist on teada 73, mõni neist ei ole küll säilinud, kuid need on teada pärimusest või varasematest allikatest. Päris täielik Odrese loetelu ei ole - tema materjalidest puudub näiteks Haljala kirikuaias asuv rõngasrist, samuti Maarja-Magdaleena ja Alatskivi kirikuaedade kiviristid. Üksikud kirjeldatud ratasristid on hilisemad (18. sajandist). Põhjasõda ja katkuaastad andsid tugeva hoobi kiviristide kasutamisele maarahva seas. Seetõttu 18. sajandist eestlaste nimesid kandvaid ratasriste ega ka muid hauatähiseid peaaegu ei leiagi. 19. sajandil tuli ratasrist uuesti hoogsamalt kasutusse, kuid nüüd juba sepisristina. 18. sajandi lõpus ja 19. sajandi alguses kasutati endisi etikukive hauatähistena, mis oma kujult meenutasid samuti ratasristi. Mitmed sellised asusid näiteks Tallinna Kalamaja kalmistul (Üprus 1971: 8), neist viis on eksponeeritud Dominiiklaste kloostri Katariina kirikus, üks ristikujuliseks tahutud etikukivi seisab aga De la Gardie kaubamajas Viru tn 13/15. Ilumäe kalmistul asub tänini samuti üks etikukivist ümberkujundatud ratasrist. Helmi Üpruse (1987) sõnul kuulub Ilumäe tähis vanimate etikukivide hulka. Vanimateks peab ta avatud õiekarikaga ehk nn roosiga kivisid. Etikukividest ümberkujundatud (ratas)ristid moodustavad eraldi grupi ja neid ei saa liigitada järgnevalt kirjeldatud ratasristi tüüpide järgi.

\section{Ristitüübid}

Eestis on erinevatel andmetel säilinud umbes 75 kivist ratasristi, mis pärinevad peamiselt 17. sajandist. Nende hulka ei ole arvatud rannarootslaste tähiseid Vormsi kalmistul ja mujal. Rannarootslased kasutasid ratasristi hauatähisena aktiivselt mõnevõrra hiljem, 18. ja 19. sajandil, ning nende tähised erinesid oma suuruselt ja kujult. Rannarootslaste ristid on eestlaste endi kasutatud rõngasristidest väiksemad. Kujult on tegu ladina ristiga, mida ümbritseb rõngas (vt joonis 1). Risti otsad võivad ulatuda ringist välja või olla kaunistatud näsadega, risti jalg võib olla erineva kujuga.

Lembit Odres (1974: 298-300) eristab kahte peamist maarahva seas kasutusel olnud rõngasristi tüüpi (vt joonis 1). Esimene neist on nn Malta rist rõngaga, kus risti harud moodustavad neli ava. Mari Loit (2004) nimetab trapetsiaalsetel hauaplaatidel sellist sümbolit ratasmaltaks. Teine tüüp on kaartest moodustunud rõngaga ümbritsetud rombi-taoline rist, kus viies ava jääb keskele. Odrese (1974: 300) sõnul võib kaartest moodustunud risti pidada kohalikuks eesti ratasristi tüübiks, sest seda ei esine sellisel kujul varasemal perioodil ega ka 
Rootsi ja Läti ratasristide traditsioonis. Sümbolina on kaarrombiga rist tuntud küll juba muinasajast, kuid selle ümber puudus ring. Loit (2004) kirjutab, et kaarrombiga risti võib leida mitmetelt trapetsiaalsetelt hauaplaatidelt, kuid keskajal hääbus selle sümboli kasutamine tasapisi. Alatiseks see siiski ei kadunud, vaid tuli 17. sajandil uuesti kasutusele kivist ratasristide ühe vormina. Seega näib mõlemal ratasristi tüübil (rõngaga Malta ristil ja kaarrombiga ristil) olevat seos trapetsiaalsete hauaplaatidega. Mõlema sümboli kasutamine taandus keskajal pärast trapetsiaalsete hauaplaatide aktiivse kasutusaja lõppu ja elavnes uuesti seoses maarahva kombega tähistada haudu kivist ratasristidega. Kuigi, nagu öeldud, lisandus kaarrombiga ristile nüüd ring, mis varem puudus, tavapärane rõngasrist tuli kasutusele endisel kujul. Ratasristide detailid ja kaunistused võivad mõnevõrra erineda või hoopis puududa - sagedasemaks kaunistuseks on nn näsad risti otstes.

Samaaegselt ratasristidega kasutati 17. sajandil hauatähisena ka tavapärasemaid kiviriste, mille haarad otstest laienesid - nn malta ristid. Erinevates allikates kasutatakse terminit 'Malta rist' (nt Loit 2004; Mäesalu 2010; Odres 1983), kuigi vormi järgi on sagedamini tegu pigem käppristiga (vt Kõuts \& Valk 1998: 12). Lembit Odres on oma materjalides koos rõngasristidega kirjeldanud vähemalt 19 Malta risti, neist kümnel on tekst või tekstikatke. Paraku ei ole ta osade tähiste juures selgelt välja toonud, kas tegu on ratas- või Malta ristiga, seetõttu analüüsin neid ristitüüpe koos.
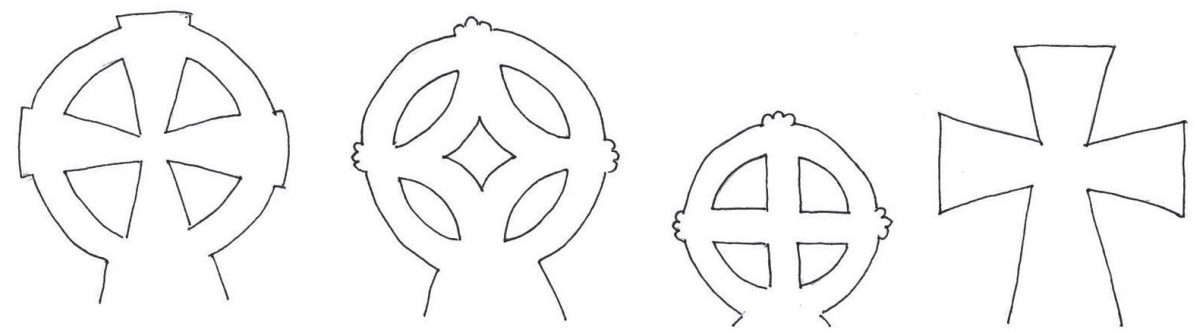

Joonis 1. Ristitü̈̈bid: Malta rist rõngaga; rombi-taoline rist rõngaga; rannarootslastele omane rõngasrist - ladina rist rõngaga; laienevate harudega nn Malta rist. 


\section{Levikuala}

Ratasristid on levinud üsna ühtlaselt kõikjal Põhja-Eesti murdealadel. Erandina ei leia neid Saaremaalt ja Pärnu ümbrusest. Lõuna-Eestis hauatähistena kasutatud ratasriste teada ei ole. Põlva kirikuseina on küll müüritud üks ratasrist ja üks Malta rist, kuid nende päritolu ei ole teada, nagu seegi, kas neid riste on kunagi kasutatud hauatähistena.

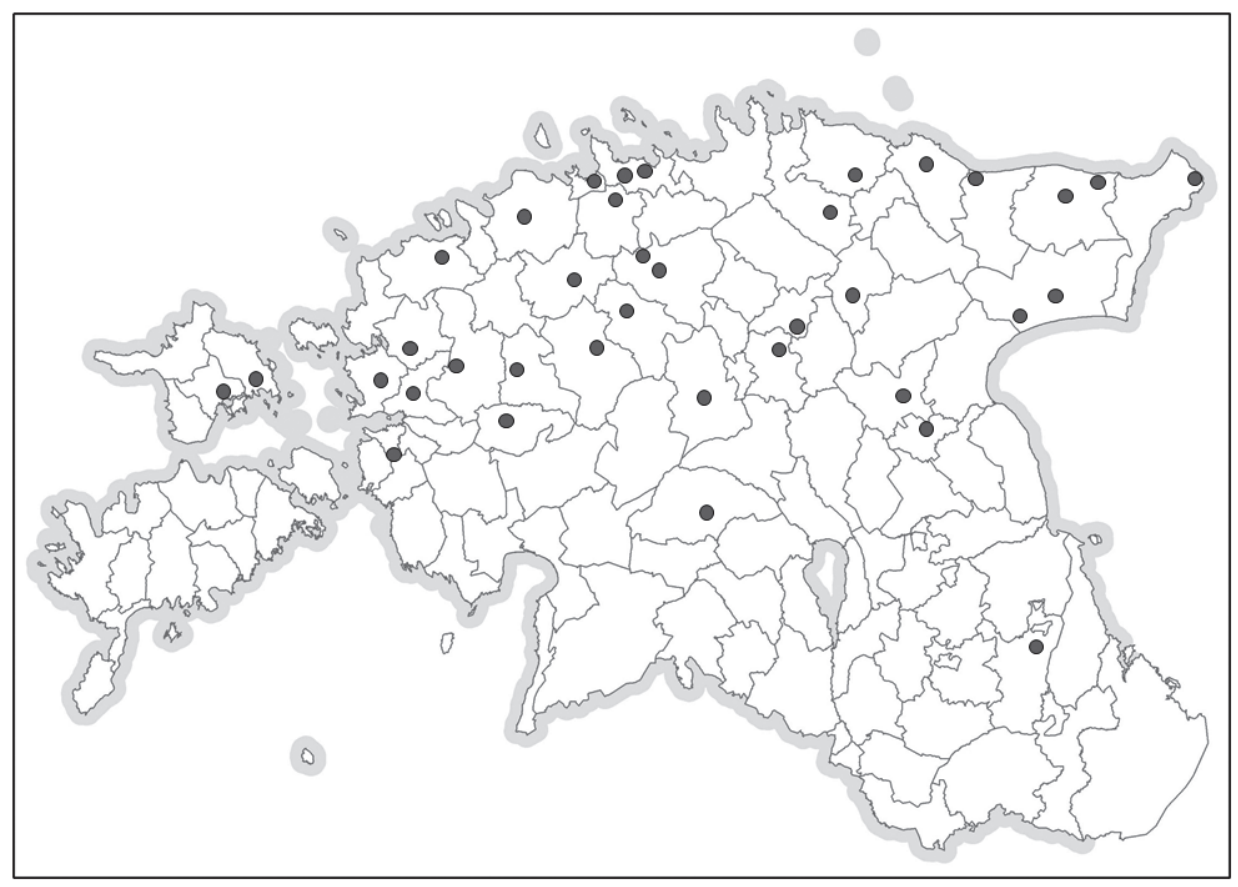

Joonis 2. 16. ja 17. sajandi Malta ja ratasristidega kirikuaiad.

Järgnevalt on loetletud kirikuaiad, kus Odrese (1983) materjalide järgi 16. ja 17. sajandi ratas- ja Malta ristid asuvad või on teadaolevalt asunud (mõned kirikuseintesse müüritult). Materjali paremaks liigendamiseks on jaotus tehtud murdealade järgi, kuna kihelkond on selleks liiga väike asustusüksus, tänapäevased maakonnad aga ei kajasta toonast olukorda. Murdealade jaotus on tehtud toetudes Jüri Viikbergilt saadud informatsioonile ning täiendatud 
raamatu Eesti murded ja kohanimed (Pajusalu \& Hennoste et al. 2009) abil. Valdavalt on tegu kihelkonnakirikute ja kirikuaedadega, väiksemate kalmistute ja abikirikute juurde on sulgudes lisatud kihelkond:

\section{Kirderanniku murderühm}

Jõelähtme kirikuaed

Viru-Nigula kirikuaed

Lüganuse kirikuaed

Jõhvi kirik

Narva

Pühajõe kabeliaed (Jõhvi kihelkond)

\section{Põhjaeesti murded}

Pühalepa kirikuaed

Käina kiriku varemed

Lääne-Nigula kirikuaed

Karuse kirikuaed

Martna kirikuaed

Märjamaa kirikuaed

Kullamaa kirikuaed

Vigala

Ridala kirikuaed

Keila kirikuaed

Hageri kirikuaed

Haljala kirikuaed

Juuru kirikuaed

Järva-Jaani kirikuaed

Järva-Peetri kirikuaed

Jüri kirikuaed

Kadrina kirikuaed

Kose kirikuaed

Laiuse kirikuaed

Palamuse kirikuaed

Rapla kirikuaed

Risti kirikuaed

Saha kabeliaed

Suure-Jaani kirikuaed

Tallinn 
Tuhala kalmistu (Kose kihelkond)

Türi kirikuaed

Vilivalla kalmistu (Risti kihelkond)

Väike-Maarja kirikuaed

Iisaku kalmistu

Tudulinna (Iisaku kihelkond)

\section{Lõunaeesti murded}

Põlva kirik

Teadaolevate ratas- ja Malta ristide arv võib ühel kalmistul ulatuda kaheteistkümneni, sagedamini on ühes kirikuaias siiski kuni neli risti. Viis ja enam risti on teada seitsmest kirikuaiast: Juuru, Karuse, Keila, Lüganuse, Märjamaa, Rapla ja Viru-Nigula (joonis 5). Tähiste tegelikku koguarvu ei ole võimalik enam hinnata.

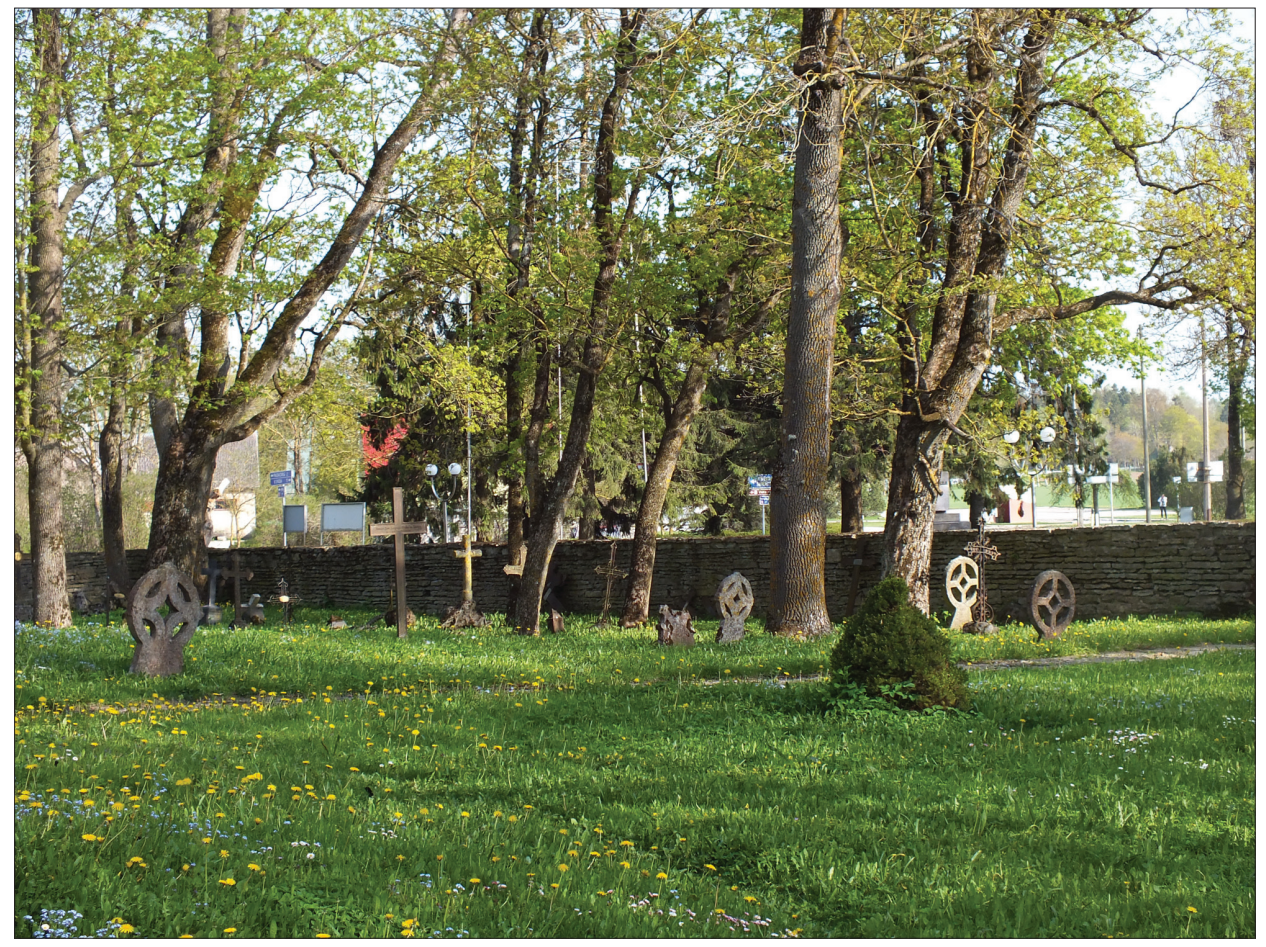

Foto 3. Ratasristid Viru-Nigula kirikuaias. Pille Arneki foto 2014. 


\section{Tekstid ratasristidel}

Järgnevalt heidame pilgu, mida ja kuidas neile 16. ja 17. sajandi tähistele kirjutati. Analüüsimisel kasutan neid 73 tähist, millel olevad tekstid on teada arhiiviallikate vahendusel - lisaks Lembit Odrese materjalidele kasutasin analüüsitavate tekstide täpsustamiseks ja parandamiseks Eesti Ajaloomuuseumi kogudes leiduvaid Hendrik Olvi ja Tallinna Linnaarhiivis olevaid Mai Lumiste ja Rasmus Kangropooli jooniseid, märkmeid ja fotosid. Nagu juba öeldud, on tegemist vabade talupoegade või mõisatöötajate (kupjad jt) hauatähistega, välja arvatud mõned erandid, millest samuti juttu tuleb. Tekstid on saksa- ja eesti-, harvem ladinakeelsed. Kohati on raske eristada, kas hauakirja on püütud kirjutada eesti või saksa keeles või on keeli segistatud (nt mõni käändelõpp vms). Aastaarvu juurde on peaaegu alati märgitud ladinakeelne anno. Tekst on enamasti risti ühel küljel, kahepoolse tekstiga riste on teada kaks.

31 tähisel on kirjas vaid isiku- ja kohanimed ning aastaarv, mistõttu keel jääb määramata. Lisaks veel mõned ebaselge tekstiga tähised. Mõnel juhul on kiviristi pind tähtede eristamiseks liialt kulunud, kuid esineb ka selliseid tekste, kus kirjutatu on loetav, ent jääb ikkagi raskesti mõistetavaks. Näiteks üks Tudulinna ratasrist kannab kirja MKNAK MKNAK MKNAK MKNAK ANNO 1671. Üheksa teksti võib määrata eesti keeles kirjutatuks, kaks (või kolm) tähist on ladinakeelsed ning 30 teksti on saksakeelsed. Pikemad tekstid tähendavad seda, et lisaks hauakirja kirjutajale pidi olema inimesi, kes oskasid seda lugeda.

\section{Vanimad eestlase nimesid kandvad tähised}

Vanim teadaolev eestlase nime kandev kivirist asus Järva-Jaani kirikuaias ja sellel oli tekst 159(3) DEN IVNIVS IST ÖNNIS NVR MICK IN GOT INSLAPEN. Lembit Odrese (1983) kirjelduse järgi leiti risti fragmendid kirikuaiast: risti haar oli pandud käimla trepiastmeks ning jalg seisis surnukuuri seina ääres. Tekstile pakkus ta kaks tähendust - õnnis noor Mick või Tõnnis Nurmick. Vahed sõna(osa)de vahel võisid mõnikord olla juhuslikes kohtades või sõna poolituskohas, seda on näha ka hilisemates tekstides. Seega ei saa ainult sõnavahed teksti tähenduse mõistmisel juhiseks olla. Teisalt on võimalik, et saksakeelse teksti sisse sattus mõni eestikeelne sõna - seda tuleb ette teistelgi tähistel, kuigi mitte sageli. Tänaseks on risti fragmendid hävinud või kaduma läinud.

Ajaliselt järgmine on Suure-Jaani kirikuaias asunud tähis tekstiga ANNE: $R$ ATTCEP 1589. Ka siin on poolituskoht ebaharilikus kohas. Tekstist allpool on Kultuurimälestiste Riikliku Registri andmeil oletatavasti ametitunnusena kivisse raiutud pesukurika kujutis. Anne Rattcepa nimi tuleneb registri and- 
meil tõenäoliselt talunimest (Rattamaa), mis omakorda viitab sellele, et talu meespere hulgas on olnud rattameister. Anne Rattcepa tähisega on seotud mitmesugused legendid. Tekst ristil on küll napp, aga tähelepanuväärne mitmes mõttes. See on teadaolevalt ainus maarahva seast pärit naisele püstitatud tähis kogu 16. ja 17. sajandi jooksul. Mõnel ratasristil on küll peremehe nime järel mainitud viimase ema või naist, kuid eraldi tähist naisele rohkem ei kohta. Ratasristid on pigem perekonnatähised, see tähendab, et enam kui pooltel ristidel on kirjas mitme inimese nimi. Anne Rattcep on saanud aga isikliku kiviristi. Ning viimaks on niisama harv, et toonasel talurahva seisusest inimesel oli üldse perekonnanimi. Tähis on viidud kirikusse sisse.

\section{Isikunimed}

Kõige olulisemaks infoüksuseks oli inimese eesnimi ehk ristinimi. Tänapäeval tundub see enesestmõistetav, kuid nime märkimine kalmudel on aja jooksul olnud erinev. Võrdluseks: suurel hulgal 19. sajandi esimese poole maarahva hauatähistest võis nimi üldse puududa ja kirjas oli üksnes aastaarv. Ratasristide hulgas on samuti palju tekstita tähiseid. Odres on maininud vähemalt 23 Malta ja ratasristi, millel tekst puudus täiesti. Nende koguarvu on aga raske hinnata, sest kui on säilinud või on kirjeldatud ainult risti fragmente, ei saa kindlalt väita, kas tähisel oli tekst või mitte. Nende ratasristide hulgas, millel on mingigi tekst peal, on nimetuid kolm (so kirjas ainult aastaarv), lisaks on neli ebaselget teksti, kus ei ole tuvastatav, kas tegu on nime või mõne muu sõnaga. 32 tähisel 73-st on kirjas ühe inimese nimi ning ülejäänud 34 tähisel on kaks või enam nime.

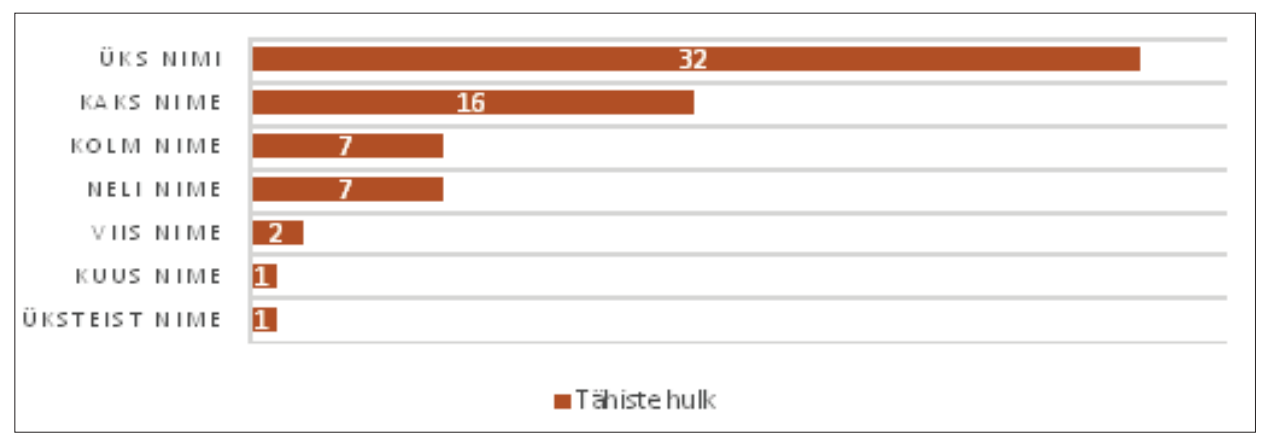

Joonis 3. Nimede arv tähistel. 
Ainult üht nime kandvad tähised ei ole üldjuhul siiski üksikisiku tähised, vaid kuuluvad perekonnale ja järglastele. Seda on mõnikord eraldi mainitud, näiteks OHWESTE JURIE KIKE KEYA TOTTER TEMMA KAHEX(A).. AP.. $O H$.. ANNO 1669. Ristil on perepea nimi, kuid see tähistab ka tema kaheksa lapse matmispaika. Või saksakeelne kiri PEPO REIN SEIN WIB VND SEINE $E R B E N A N$ 1677, kus kirjas on üks nimi, kuid mainitud on ka naist ja järglasi. 30 tähisel ehk $41 \%$ on kirjas kaks kuni neli nime. Viie ja enama nimega tähiseid kohtab harva, kuid selle üks põhjuseid on asjaolu, et kiviristi pind seab oma piirangu teksti pikkusele. Pikk nimekiri ei mahuks tähisele lihtsalt ära. Kõige markantsem näide on Iisaku kirikuaiast, kus ühel tähisel on üles loetletud ühe suguvõsa üksteist meest ja nende omavahelised sugulussuhted: IWAHN PEPO POÜCK LUCKA PEPO POÜCK PETER PEPO POÜCK IAHN PEPO POÜCK PEP LUCKA POÜCK MICHEL LVCKA POÜCK PETER POÜCK MÜTER IWANA POÜCK PETER IWANA POÜCK PEP IANE POÜCK WAHSELL ANNO 1669. Tekstist nähtub, et vanaisa Pepol (Peep) on olnud neli poega - Iwan, Lucka, Peter ja Iahn (so Jaan), kelle pojad omakorda on üles loetud.

Kõigil tähistel kokku on mainitud 140 erinevat isikunime, neist vaid 13 on naisenimed. Naisi on mainitud seoses perepeaga (naine, tütar või ema). Ainus erand selles osas on Anne Rattcepa juhtum: tema on saanud isikliku tähise. Kui tegemist on loeteluga, siis on esikohal mehe nimi. Üks tähis äratab selles osas veel tähelepanu - Türi ratasristil on tekst WANA EWA IAHN VND SEINE $E(R B) E N H A N S$ MATZ. Tõenäoliselt on siin tegemist siiski ema nimest saadud lisanimega - Wana Ewa. Tähis ise on püstitatud Jaanile ja tema järglastele. Selline lisanimi on küll harv, aga siiski mõnel pool esinev. Nii on ka seletatav, miks on eestikeelne sõna wana sattunud saksakeelsesse hauakirja.

Kõige sagedamini kasutatavad eesnimed on Jurgen (esines 14 korda), Hans (11x), Tönnis (9x), Ihan (9x), Iack (8x). Need viis levinumat nime moodustavad 2/3 kõigist eesnimedest. Sealjuures nimede kirjapildi varieeruvus on väga suur. Näiteks nime Jurgen on kirjutatud seitsmel moel ja kohati on keeruline tuvastada, kas tegu on ikka sama nimega. Mõned näited nimede variatsioonidest:

Jurgen: Jergen, Gergen, Ivrgen, Ivrge, Irgen, Jurgen, Jören

Jaan: Jaen, Ian, Iahn

Juhan: Ihan, Johan, Iohan

Sageli korduvad eesnimed nõuavad enda kõrvale lisanime. Vaid neljal tähisel oli kirjas üksnes ristinimi (Peter, Mikk) ja lisanimi puudus. Kui tähisel on mainitud lapsi/järglasi, siis nende juures võib üksiknimesid olla rohkem, sest isanimi või talunimi on eespool juba mainitud. Lisanimedeks võivad olla: 
1. Isanimi (ühel juhul ka emanimi): Davida Peter, Pepo Rein, Andrese Mart, Wana Ewa Iahn. Selliseid täiendeid esines kokku kuuel ristil üheksa nimega. Lisaks sellised tähised, kus on välja toodud, et tegemist on kellegi pojaga (nt Iwan Pepo poück).

2. Talu-/küla- vms kohanimi: Mosekull Pette 'Mõisaküla', Meepere Matz 'Mäepere Mats', Tvirre Lavr 'Türi Laur'. Need on kõige levinumad lisanimed (28 tähist 56 nimega), samas ka kõige raskemini eristatavad kas tegu on ikka kohanimega või hoopis isanimega (mõnel juhul) vms täiendiga.

3. Perekonnanimi, mis paikneb ristinime järel: Tönnis Nurmick, Peter Rautsep, Hans Iohanson, Nicolaus Meaz. Need on enamasti ühele inimesele püstitatud tähised, vaid kahel tähisel oli kaks isikunime. Kokku on selliseid tähiseid 13, millel omakorda 15 nime.

Eestlaste perekonnanimede panek toimus Liivimaa kubermangus aastail 18231826 ning Eestimaa kubermangus 1835 (Tiik 1987: 84-85). Kuid perenimi võis vabadel talupoegadel ja mõisatöötajatel olla juba ka varem. Kõnekas on see, et perenimega tähised on üldjuhul üksikisiku tähised - ilmselt olid nad oma eluajal saavutanud parema sotsiaalse staatuse, mis kajastub nii nimes kui ka hauatähises.

\section{Daatumid}

Nime kõrval teine oluline infoüksus on aastaarv. Enamasti on aastaarvu ees ladinakeelne $A N N O$ või lühendid samast sõnast $A O$ / $A$ / $A N$. Seda kasutatakse nii saksa- kui ka eestikeelsetes tekstides, kusjuures sõnu aasta või jahre ei kasutata aastaarvu märkimisel kordagi. Sünnikuupäeva ega -aastat ei olnud toona kombeks märkida - sünnidaatumid puuduvad lisaks Malta ja ratasristidele ka kirikutes asuvatel kõrgest seisusest inimeste hauaplaatidel. Muid hauatähisetüüpe 17. sajandist teada ei olegi.

Sünniaja märkimise komme muutus eestlaste seas valdavaks alles 19. sajandi teisel poolel. Täpne surmakuupäev on märgitud kümnele saksakeelsele tähisele. Mõnel juhul on mainitud tähise püstitamise aasta. See omakorda külvab segadust - võimalik, et nii mõnelgi teisel tähisel pole kirjas surmaaasta, vaid hoopis tähise püstitamise aasta. Kiviristi tegemine oli kallis ja aeganõudev töö ning pole võimatu, et rist toodi hauale hiljem. Kuidas muidu seletada asjaolu, et enam kui pooletele tähistele on korraga raiutud mitme inimese nimi - kõrgkirja puhul ei ole võimalik nimesid hiljem juurde kirju- 
tada, süvendkirjaga selline võimalus küll jääb, kuid kogu teksti samaaegsele raiumisele viitab lisaks nimede paigutusele seegi, et aastaarv on ainult kõige viimase nime järel. Üksikutel tähistel on lisaks nimeliselt kirjas, kes on selle ratasristi lasknud panna.

Neljal saksakeelsel tähisel on mainitud inimese vanust ja seda eri vanuses inimeste puhul (alates 14aastasest kuni kuuekümnesteni). Vanuse märkimine oli levinud üsna laialdaselt kuni 19. sajandi keskpaigani, mil vanust hakkas asendama täpne sünniaeg. Pirita kloostri kalmistu 19. sajandi kiviristidel on vanuse märkimine valdav. Näiteid leiab teisteltki (peamiselt maapiirkondade) kalmistutelt, kus saksakeelsete (baltisakslaste) tähiste eeskuju on tagasihoidlikum. Lääne-Nigula kirikuaiast pärineb tekst: PILLE IACK SEIN WEIB EDDA PILLE HANS PILLE MARDT VNDT ALLE SEINE SOHNS NNO 1675 JAHRT 67 (tõlkes: Pille Jaak tema naine Eda Pille Hans Pille Mart ja kõik tema pojad anno 1675 vana 67). Märgitud on perepea vanus ning oletatavasti tema surma-aasta. Aastaarvu asukoht vanuse ees näib viitavat sellele, et tegu ei ole risti püstitamise aastaga. Teiste pereliikmete daatumid on jäänud märkimata,

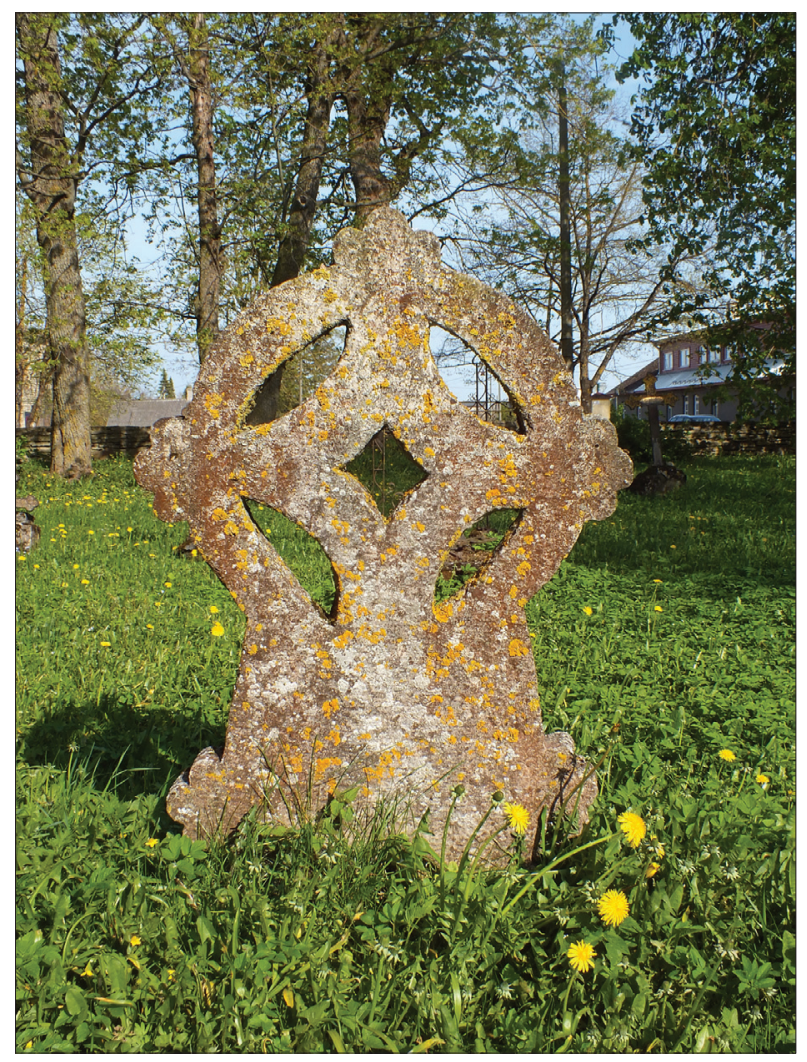
nagu kõigil teistelgi tähistel. Ratasrist tähistab matmis- ja mälestuspaika, kas aga kõik pereliikmed sinna maetud on, ei ole teada. Näib, et kivist ratasristid ei ole pelgalt hauatähised, vaid pigem kogu perekonna staatuse ja väärikuse sümbolid. Nii ei olnud ka oluline kõikide pereliikmete täpseid daatumeid kirja panna.

Foto 4. Ratasrist Viru-Nigula kirikuaias. Pille Arneki foto 2014. 


\section{Sugulussuhted}

Pereliikmete täpseid surmaastaid ei ole mainitud, kuid sageli on mainitud nende seos perepeaga (ristil esimesena mainitud inimesega), so sugulussuhted: poück / boig / boyk, tyttar, nain (saksakeelsetel sageli erben). Eestikeelsetel tähistel on kõige sagedamini mainitud poega, ühel korral tütart, naist ja lapsi üldisemalt. Saksakeelsetel on samuti kõige sagedamini mainitud poega/poegi (9x), pärijad või lapsi (9x), naist (6x), ühel korral ka tütart, venda, ema või isa. Ühel tähisel on eraldi märgitud, et tegemist on seadusliku pojaga.

\section{Teksti ülesehitus}

Kirikutes olevatel hauaplaatidel on tekst esitatud jutustavate lausetena. Näiteks ühe Narvas asunud ladinakeelse teksti sisu on tõlkes järgmine:

Aastal 16(43?) 21. novembril uinus Issandas magama kõrgest-sündinud, kõrgeauline ja hästitoiminud Claes Eeriku poeg Blatsman, proviant- ja rentmeister Narva ja Jaanilinna üle. Jumal olgu ta hingele armuline (Sild 1928: 8).

Ratasristidel on kasutatud erineva struktuuriga tekste. Kõige sagedamini on kirjas üksnes mõned faktid - nimi ja/või surma-aasta; küla, talu või mõisa nimi. Selliseid tähiseid on kokku 32, ehk $42 \%$ kõigist analüüsitud tähistest, nt (A)RLA PETER NIGOLAS KULTSARVELT S ANNO 1629. Üheksal saksakeelsel ja kolmel eestikeelsel tähisel (kokku 16\%) on lisaks eelnevale infole lisatud andmed sugulussuhete kohta, kuid sidusat lauset moodustatud ei ole ja andmed on üles tähendatud fraasidena: SERKE SIBBE IAK IAKO BOIG IRGEN IRGE BOIG MADDI AO 1695 või PEPO REIN SEIN WIB VND SEINE ERBEN AN 1677. Mõlemad tekstid pärinevad Lüganuselt.

Vähemal määral esineb elliptilisi lauseid, kus on selgelt tajutav, et mõni oluline lauseliige on puudu. Elliptilisteks võib lugeda seitset teksti (10\%), kõik saksakeelsed. Võimalikuks põhjuseks on ebapiisav saksa keele oskus või puudulik keeletaju. Teisalt oli oluline teksti sisu edasiandmine ja vormilisele küljele ei pruugitudki väga suurt tähelepanu pöörata, seda enam, et toonane kirjakeel oli väga varieeruv, nt DIESE STEIN SIMO MARTINSON V. ODORIS (Jõhvi). Viimase grupi moodustavad 17 saksakeelset ja kolm eestikeelset teksti (kokku 27\% kõigist tekstidest), mis on esitatud jutustavate lausetena ja sarnanevad ülesehituse poolest kõige rohkem kirikutes asuvate hauaplaatide tekstidele. Sobiva saksakeelse näite leiab Vilivalla kalmistu kiviristilt: HIER LIEGT BEGRABEN MAT3I MVSTIVS SEN WEIB (naise nimi on ümber 


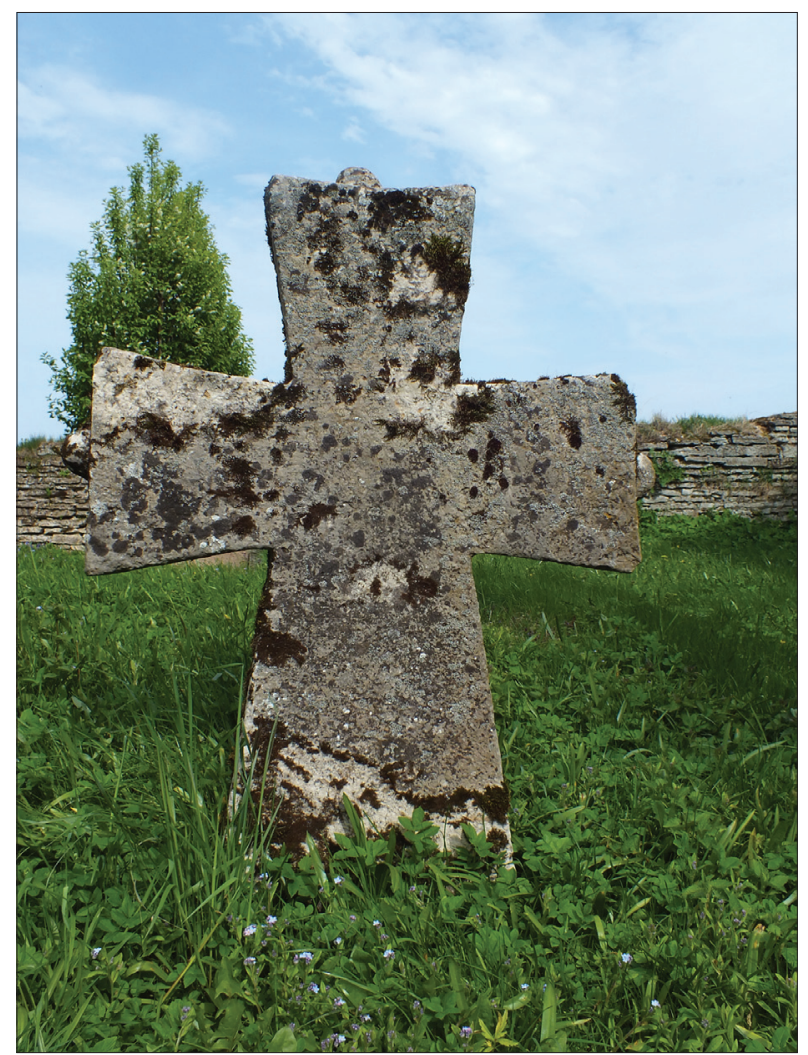

Foto 5. Malta rist Lüganuse kirikuaias. Pille Arneki foto 2014.

raiutud) VND ALLE SEINE KINDER ANNO 1654 DEN 28 FEB. Sellised tekstid algavad või lõpevad mõne nendinguga (sulgudes on märgitud esinemissagedus):

eestikeelsetel: siin maggab / magkap (2x);

saksakeelsetel: siin on / siia on maetud (3x);

see kivi kuulub / selle kivi on teinud ...(7x);

... (kellele) on see rist pandud / ... oma on see rist (1x);

magab (õndsalt) Jumalas (2x); Jumal kutsus tema hinge.

Kolm tähist ei kuulu nime järgi kindlasti eestlastele, need kõik on saksakeelsed. Ka eestlaste nimed on tihti saksapärased ning mõne nimekandja päritolu jääb selgusetuks. Ühel selgelt võõrapärast nime kandval tähisel on lõpulauseks olgu Jumal talle armuline ning teisel on teksti lõpus aamen. Piiblitekstid vms 
salmid puuduvad ratasristidel täiesti, vaid viiel tähisel on mainitud Jumalat, neist kaks on võõramaist nime kandvatel ristidel. Ka kaks eestlase nimega teksti ei kuulu tegelikult 17. sajandisse - üks neist on juba eespool mainitud vanim ratasrist aastast 1593 ning teine pärineb 18. sajandi algusest VäikeMaarja kirikuaiast ning kannab kirja GOTT SEI DER SEELEN GNEDIG ANN 1718 DEN 19 ANGNSTY (?) WISTLAST MICHKKLE MATIS (tõlkes: Jumal kutsus tema hinge a 1719 19. augustil Wislast Michkle Matis). Kahel eestikeelsel tähisel on mainitud maetu vagadust. Teadaolevate tekstinäidete põhjal selgub, et 17. sajandil maarahvale püstitatud ratasristidel leiab otseselt kristliku maailmapildiga seotud märksõnu vaid üksikjuhtudel, kuigi ratasristid ise asusid kirikuaedades.

\section{Päritolu}

Erisugust lisateavet maetu kohta leidub samuti pigem üksikjuhtudel. Sagedamini on mainitud päritolu küla, talu või mõisa nimi, mis on tihti esitatud lisanimena ristinime ees. Kohanimede tuvastamine on omaette teema, mis vajaks eraldi põhjalikku süvenemist. Erinevad autorid/uurijad on mõningaid võimalikke tähendusi pakkunud, nt TVIRRE - Türi; IETZE - Jõetse küla; MEAZ - Mäeots; RINGOTTO - Ringuta küla; KODDA ASSEME - Kodasma küla jne. Harvem esineb päritolukoht lauses/fraasis sellises positsioonis, kus on vajalik kasutada käändelõppu. Ühel Viru-Nigula saksakeelsel tähisel on sel moel teksti sisse sattunud eestikeelne käändelõpp: LALLE IACK PADA KVLAST A o 1653 LALLE REIN LALLE HIN LALLE SIEM LALLE IAHN LALLE IVRGE HORET DIS STEIN. Samasugune pisiviga leidub veel ühel saksakeelsel tähisel.

\section{Elukutse, iseloomujooned jm lisainfo}

Elukutset on mainitud harva. Ühel eestikeelsel tähisel on kirjas KUBJAS, saksakeelsetel: kubjas, kõrtsmik, mölder ning lisaks FREIBAWR (vabatalupoeg). Inimest iseloomustavaid seiku mainitakse eestikeelsetel tekstidel kahel korral, mis tähendab, et need hauakirjad on pigem erandlikud. Juuru kirikuaia ratasristil on tekst ANNO 1687 SIIN MAGGAB PAIA IOST X AVW S WANNA MEES KES ELLAS WAGGASTE HIHCJ SVRI SKKOS (tänapäevases vormis: Siin magab Paia Joost üks aus vana mees, kes elas vagalt ning suri usku/ usus). Ühelt Keila ratasristilt võib lugeda SIGN MAGKAP TAMME HANS YKS KINDEL AUS MEHS KES ELLAS AU SEHS TAMME JOHAN VSKAHS NINC SURRIS VSKO TAMME HANS TAMME TOMAS TAMME MARI (so Siin ma- 
gab Tamme Hans, üks kindel aus mees, kes elas au sees. Tamme Johan uskus ning suri usku, Tamme Hans, Tamme Tomas, Tamme Mari). Mõlemal juhul on kirjeldus seotud maetu vagaduse ja usuga. Need kaks teksti on kirjutatud ladusas eesti keeles ja seetõttu võib oletada, et tekstikirjutaja emakeeleks oli samuti eesti keel.

Saksakeelsetel maarahva tähistel on kahel korral maetu nime ees märge 'vana' (nt ALTEN IRGEN so vana Jürgen). See on seotud pigem põlvkonna määratlemisega, mitte otseselt vanuse rõhutamisega. Vaid ühel tähisel on isiklikum ja emotsionaalsem väljend LIEBE VATER (kallile isale). Tähelepanu äratavad kolme võõrapärase nimega mehe hauakirjad, mis sõnakasutuse poolest eristuvad maarahva tähistest. Neist kahel on märge SELIG / SELICHE (õnnis, õnnistatud/õndsalt) ja ühel iseloomustavad sõnad $\operatorname{ELDEN} U N D \operatorname{MAN}(N)$ (õilis/üllas ja mehine). Viimane on iseloomulik kõrgemast seisusest inimeste hauakirjadele.

\section{Vägivaldsed surmad}

Surma põhjuseid mainitakse ristikirjades harva. 17. sajandil ega ka hiljem pole hauakirjades kordagi mainitud mingit surma põhjustanud haigust. 19. sajandist on teada tähiseid, kus on lühidalt kirjeldatud õnnetusjuhtumeid. Ratasristidelt leiab surma põhjuse vaid vägivaldsete surmade korral. Selliseid tekste on kokku teada neli, neist kaks kohalikku päritolu meeste ristidelt ja kaks võõramaalaste tähistelt. Kõik tekstid on saksa keeles, küllap on keelevalikul määravaks lugejate sihtrühm:

- DIESER STEINGEHORETALBRECHTBERENTSONGEWESENEN KRVGER ALHEIMDORFEN (SEI)NEN ERBEN WELCHER AO 1675 D 24 SEP TAGES DÖRF (F)ELDE MIT EINER AXTERSCHLAGEN WARD D 22 OCTO SELIG GESTORBEN DESSEN SEELEN GOT GNEDIG

[See kivi kuulub Albrecht Berentsonile, kes oli Alheimdorfis kõrtsmikuks. Tema järglaste jaoks. A 1675 24. sep. päeval külapõllul kirvega maha löödi, 22. oktoobril õndsalt suri. Tema hingele olgu Jumal armuline]

- ANNO9ODEN4FEBRUARISTDERRUSSEIMDASSCHWEDISCHE IAGER GEVALEN UND HAT DEN EDLEN UND MAN(N) HAFTEN VASILI RASLA(DIN) ERSEHLAGEN

[90. aastal 4. veebruaril on venelane Rootsi laagri kallale tunginud ja õilsa ning mehise Rasladini maha löönud] 
- WASSAMA HANS MOLLER THOMAS WASSAMA MOLLER IST ERSCHLAGEN A1638

[Wasama Ants Moller Toomas Wasama Moller on maha löödud a 1638]

- ANNO 1611 DEN 1 DECEMBER WORT SOSO TONNIS GESCATTEN

[Aastal 1611 1. detsembril sai Soso Tonnis maha lastud]

Viimase ratasristi kohta kirjutab Jaan Jung (1910), et üks Poola soldat olevat selle Tõnise püssiga maha lasknud, kui see parajasti kirikust välja astunud. Johan Naha Harjumaa käsikirjast leiab pisut teise variandi (Odres 1983): poolakad olevat läbi kõrtsi akna lasknud ühe mehe maha. Sellele olla pandud see ratasrist.

\section{Kuidas kirjutati!}

Osa tekste on oskuslikult kivisse raiutud ja nende kirjutajaks võis olla tähise valmistanud meister, teine osa on aga kohmakamad ja vähem viimistletud ning need võis tähisele kirjutada kohapeal mõni külamees. Enamasti on hauakirjad kirjutatud läbivate suurtähtedega. Tekstid ratasristidel on suhteliselt lühikesed - fraasist paari-lauseliste kirjadeni. Mitmel juhul on laused elliptilised, so puudub mõni oluline lauseliige (sagedamini tegusõna). Seetõttu saab eelkõige jälgida ortograafiat, vähem morfoloogiat ja süntaksi. Isiku- ja kohanimede analüüsimisel ei ole oluline, kas ülejäänud tekst on kirjutatud eesti või saksa keeles, sest nimed on kirjutatud tõenäoliselt ikka harjumuspärasel moel - kui seda saab üldse harjumuseks nimetada, sest kirjakeelt läks toona maal elaval eestlasel harva tarvis (nt AO 1667 DEN 5 APRI REBASE HANS KVBIAS ZV $H A G$...). Samale nähtusele viitavad veel kaks saksakeelset hauakirja, kus kohanimele on lisatud eesti keele käändelõpp või kus on kirjas eestikeelne täiend 'küla'. Ühel saksakeelsel tähisel on kuunimele lisatud eesti keele käändelõpp ja seda samal tähisel kahel korral (ANNO 1624 DEN 17 NOWEMBRIS IST KASSOMEHS HANS [...] VND IHREN ERBEN ZV DEN 4 NOVEMBRIS).

Kirjavahemärke ratasristide tekstides üldjuhul ei kasutata, välja arvatud mõned koolonid sõnavahe märkimiseks. Poolitamine tähendas sõna katkestamist juhuslikus kohas, samas ruumipuudusel vms põhjusel võidakse kokku kirjutada suvalised sõnad. Poolitamisel jätkati sõna uuelt realt, kuid mingisugust kirjavahemärki sealjuures ei kasutatud. Tekst Lüganuselt:

SERKE

$S I B B E$

SIBBE IAK 


\section{IAKOBOIGIR}

GEN:IRGEBO

IGMADDI

AO 1695

Sellel tähisel on kirjas nelja mehe nimed: Serke Sibbe (?), Sibbe poeg Jaak, Jaagu poeg Jürgen, Jürge poeg Maddi. Aastaarvud on kirjas araabia numbritega, vaid ühel tähisel on kasutatud Rooma numbreid. Toonasele ortograafiale on omane, et mitmeid tähti kirjutatakse ühtmoodi ja seda nii eesti- kui ka saksakeelsetel tähistel: $\mathrm{U}$ asemel $\mathrm{V}$ ja J asemel I (nt RAVTSEP, MOSEKVLL, KVBIAS, IVRGEN), harvem $\mathrm{N}$ asemel $\mathrm{H}$ ja G/K asemel $\mathrm{C}$ (nt HIHCJ, NINC, CVRTNA). Mõned tähed on aeg-ajalt kirjutatud peegelpildis $-N, S, E$, kusjuures $E$ meenutab sel juhul pigem numbrit 3 . Nimedes on mõnikord täishäälikuid ära jäetud (Irgen so Jurgen, Ihan so Juhan).

Raimo Raag (2008: 14) kirjutab, et vastne kirjakeel oli keeleliselt küllaltki kirju ja sõltus kirjapaneku(te) autori keelelisest taustast ja haridustasemest. Ratasristidelt on näha, et kohati on järgitud Stahli eeskuju/soovitusi, jälgitavad on ka mõned ajastuomased keelemuutused. Toetudes Heli Laanekase (2004: 17-25) välja toodud 16. ja 17. sajandi Põhja-Eesti kirjakeele iseärasustele, jäävad hauakirjades silma:

1) saksa ortograafiale omased võõrtähed ja võõrtähtühendid: $M I C K, B V X S V$ 'Buksu', KAHEXA 'kaheksa', IETZE 'Jõetse' jne;

2) waggaste - Stahli sõnatuletuse st(e)-liiteline viisiadverb (samas: 23);

3) $h$ - pikendusmärgina, nt Iahn, sehs. Samas võrdluseks võib eestikeelsetel tähistel leida selliseid sõnu, kus (üli)pikk vokaal on kirjutatud kahekordse tähega, nt mees;

4) Stahl kasutab saksa keele eeskujul sageli käändeid kaassõnade abil, hauakirjades esineb seda korra: au sehs;

Põhja-Eesti kirjakeele variantsus kajastab tollaseid muutusi eesti keeles (samas: 24). Mõningaid näiteid muutuste kohta leiab samuti hauakirjadelt, kus kohati on kasutatud vana, teisal jällegi muutunud vormi:

5) auws vrd au - v kadumine labiaalvokaali kõrval;

6) magkap vrd maggab - klusiilide nõrgenemine sõna sees ja lõpus, mis võib olla siinsete näidete puhul ka üksnes ebajärjekindlus. 
Eestlaste hauakirjade hulk näib olevat võrdelises seoses eestikeelsete trükiste arvu kasvuga 17. sajandil ja ühtlasi lugemisoskuse edenemisega. Eesti kirjakeele tekkesajandist ehk 16. sajandist pärinevad kindlad andmed seitsme eestikeelse trükise ilmumise kohta (Raag 2008: 28), järgmisest sajandist on teada kaheksakümmend seitse trükist (samas: 35). Eestlaste nimedega hauatähiseid on 16. sajandist teada kaks. Järgmisel sajandil suurenes eestikeelsete trükiste arv tunduvalt, siiski nendib Raimo Raag, et need ei olnud mõeldud eestlastele, vaid saksa ja rootsi soost kirikuõpetajatele. Küll aga olid eestlastele mõeldud esimesed aabitsad ja 1686. aastal Riias ilmunud lõunaeestikeelne Wastne Testament (Raag 2008: 31). Seega pidi leiduma juba ka lugeda oskajaid. Uno Liivaku (1995: 20-21) oletab, et 16. sajandi esimesel poolel, WanradtKoelli katekismuse ilmumise ajal, võib eestlaste lugemisoskust hinnata ühele protsendile rahvaarvust, sajandi teisel poolel võis see olla kaks protsenti ning sajandi lõpuks kasvas veelgi. 17. sajandi alguses võis lugeda oskajaid eestlaste hulgas olla juba $10 \%$ ja enam ning nende osakaal suurenes järgneva sajandi jooksul märgatavalt (Laanekask 2004: 20). Ka eestlaste haudu hakkasid sel sajandil üha sagedamini tähistama kirjadega ratasristid, mis annavad tunnistust lugemisoskuse suurenemisest - poleks ju vajadust kirjutada teksti, kui seda ei osata lugeda.

Kokkuvõtteks on kivist ratasristid olnud hauatähistena perekonna väärikust ja identiteeti kandvad sümbolid, kus olulisel kohal on perepea nimi. Neid ei paigaldatud igaühele, tegemist on pigem erandlike jõukamatele talupoegadele ja mõisatöötajatele püstitatud tähistega. Ratasristid olid kasutusel Põhja-Eestis, kuid üksikuid tähiseid leidub ka lõuna pool. Valmistati neid piirkondades, kus paekivi oli kergesti kättesaadav. Suurte ja raskete ratasristide transport oli keerukas ning ilmselt tehti seda talvisel ajal. Need tähised on tähelepanuväärsed nii kunstiajaloo, usundiloo kui ka kirjakeele ajaloo seisukohalt. 


\section{Arhiiviallikad}

Harjumaa kihelkondade ratasristide joonised H. Olvi annotatsioonidega. Eesti Ajaloomuuseum, f 310, n 1, s 75.

H. Olvi koostatud nimestikud ja märkmed ratasristide kohta. Eesti Ajaloomuuseum, f 310, n 1, s 81 .

Läänemaa kihelkondade ratasristide ja hauaplaatide joonised ja fotod $\mathrm{H}$. Olvi annotatsioonidega. Eesti Ajaloomuuseum, f 310, n 1, s 77.

Odres, Lembit 1983. Eesti rõngasristid. Kd I - uurimistöö kokkuvõte. Muinsuskaitseameti arhiiv, f T-76, n 1, s 11383.

Odres, Lembit 1983. Eesti rõngasristid. Kd II - uurimistöö kokkuvõte. Muinsuskaitseameti arhiiv, f T-76, n 1, s 11384.

Rasmus Kangropooli ja Mai Lumiste isikuarhiiv. M. Lumiste. Raidkivikunst - kirjeldused hauaplaatidest, epitaafidest ja rõngasristidest. Tallinna Linnaarhiiv, f R-242, n $1, \mathrm{~s} 249$.

Rasmus Kangropooli ja Mai Lumiste isikuarhiiv. Mai Lumiste kirjeldused Ida-Eesti ekspeditsioonil leitud esemetest - ikoonid, lühtrid, altarimaalid, rõngasristid jne. Tallinna Linnaarhiiv, f R-242, n 1, s 322 .

Ratasristide fotosid Eesti kalmistutelt. Eesti Ajaloomuuseum, f 310, n 1, s 80.

Tallinna ja selle ümbruse (Pirita, Saha) ratasristide ja hauaplaatide joonised ja fotod H. Olvi annotatsioonidega. Eesti Ajaloomuuseum, f 310, n 1, s 76.

Tartu- ja Järvamaa kihelkondade ratasristide joonised ja foto H. Olvi annotatsioonidega. Eesti Ajaloomuuseum, f 310, n 1, s 79.

Virumaa kihelkondade ratasristide ja hauaplaatide joonised $\mathrm{H}$. Olvi annotatsioonidega. Eesti Ajaloomuuseum, f 310, n 1, s 78.

\section{Kirjandus}

Caune, Andris 2008. Riņ̧̧a krusti Latvijā. Riga: Latvijas vestures instituta apgads.

Jung, Jaan 1910. Muinasajateadus eestlaste maalt. III. Kohalised muinasaja kirjeldused Tallinnamaalt. Tartu: Postimees.

Kultuurimälestiste Riiklik Register (http://register.muinas.ee/?menuID=monument\& mtab=general -11 . juuni 2011).

Kõuts, Eerik \& Valk, Heinz 1998. Rist ja raud. Põhja-Eesti külaseppade 18. ja 19. sajandil tehtud kalmuriste. Tallinn: SE \& JS.

Köögardal, Ado 1924. Keila kihelkonnaloost. Tallinn: Tallinna Eesti Kirjastus-Ühisus. Laanekask, Heli 2004. Eesti kirjakeele kujunemine ja kujundamine 16.-19. sajandil. Tartu: Tartu Ülikooli Kirjastus. 
Liivaku, Uno 1995. Eesti raamatu lugu. Tallinn: Monokkel.

Loit, Mari 2004. Trapetsiaalsed hauaplaadid Eestis. Tallinn: Muinsuskaitseamet.

Markus, Kersti 2003. Vanimad kristlikud hauatähised Eestis. Mägi, Marika (toim). Eesti aastal 1200. Tallinn: Argo, lk 107-124.

Odres, Lembit 1974. Ühest vanemast kunstimälestiste liigist kalmistuil. Tarmisto, Vello (toim). Harju rajoonis: kodu-uurijate seminar-kokkutulek 11.-14. juulini 1974. Artiklite kogumik. Tallinn: Eesti NSV Teaduste Akadeemia Kodu-uurimise Komisjon \& Eesti Geograafia Selts.

Odres, Lembit 2000. Rõngasristid - Eesti toponüümia allikas. Eilart, Jaan (koost). Raamatulooline Eesti. Kodumaa tundmise allikad. Tartu, lk 99-101.

Mäesalu, Ilme 2010. Hauatähised. Ajalugu ja hooldus. Tallinn: Muisuskaitseamet (http:// www.polva.ee/bw_client_files/polva_linn/public/img/File/kalmistu.pdf-11. juuni 2014).

Pajusalu, Hennoste et. al. 2009 = Pajusalu, Karl \& Hennoste, Tiit \& Niit, Ellen \& Päll, Peeter \& Viikberg, Jüri 2009. Eesti murded ja kohanimed. Tallinn: Eesti Keele Sihtasutus.

Raag, Raimo 2008. Talurahva keelest riigikeeleks. Tartu: Atlex.

Sild, Olaf 1928. Mõningaid vanu hauakive meie maalt. Über einige alte Grabsteine in Estland (Referat). Tartu: Mattiesen.

Tiik, Leo 1987. Perekonnanimede panekust Eestimaa talurahvale 1835. aastal. Keel ja Kirjandus 2, lk 83-88.

Valk, Heiki 1994. Kirikaiad ja külakalmistud. Horisont 7, lk 28-33.

Üprus, Helmi 1971. Tallinna etikukivid. Tallinn: Valgus.

Üprus, Helmi 1987. Raidkivikunst Eestis XIII-XVII sajandini. Tallinn: Kunst.

\section{Summary}

\section{Wheel Crosses - 17th Century Grave Monuments in Northern Estonia}

Pille Arnek

Keywords: epitaph, grave markers, language history, wheel crosses, 17th century

The earliest grave markers on the territory of Estonia are trapezium-shaped grave plates from the 13th-14th centuries - they show different symbols but usually no text. Gravestones in churches mostly date back to the 14th-17th centuries, but usually no Estonian names appear on them. The oldest partly preserved grave monuments bearing Estonian names are wheel crosses in churchyards in Northern Estonia, mainly originating from the late 16th century and 17th century. These are masterful monuments with fine finishing, bearing fragments of texts from the early period of written Estonian language. Regarding the frequency of their occurrence, wheel crosses are rather rare 
grave monuments which could not have been afforded by just any peasant. The texts on them were in German or Estonian, also some in Latin. In addition to names and dates, the text include information about the family, their trade and parentage, village names and other facts. Texts on these crosses gives information how literate were the masters who made them. In order to understand wheel crosses more fully, their art historical, ethnographic and religious background must be considered in addition to their linguistic aspects. 